\title{
Efektifitas Antibiotik Pasien Demam Tifoid Rsup Dr. M. Djamil Padang
}

\author{
Ayu Rahmawati1, Husni Muchtar ${ }^{2}$, Hansen Nasif 3 \\ 1Program Studi Farmasi, STIFAR RIAU, Indonesia, ${ }^{2}$ Fakultas Farmasi, \\ Universitas,Andalas, Indonesia, ${ }^{3}$ Fakultas Farmasi, Universitas Andalas, Indonesia \\ 1ㅁahmawatiayu@umri.ac.id, 3 hansenn ina@yahoo.com
}

\begin{abstract}
To find out the effectiveness of antibiotics in typhoid fever patients at the SMF of Pediatric and SMF in Internal Medicine Dr. RSUP M. Djamil Padang. This study was a cross-sectional study with a retrospective type of data during 2012 and prospective from June to September 2013, with a descriptive analysis design. The number of patients who met the inclusion criteria were 11 patients. Percentage of antibiotic use in adult patients for ceftriaxone (60\%) and chloramphenicol (40\%). The percentage of antibiotic use in pediatric patients for ceftriaxone, chloramphenicol, and cefixim are $60 \%, 27 \%$, and $13 \%$, respectively. Fever free for ceftriaxone and chloramphenicol in pediatric and adult patients, each of which is 2-3 days and 4-6 days; 3-4 days and 4 days. To be free of cefixime fever in pediatric patients is 2 days. The length of treatment required is ceftriaxone and chloramphenicol (children and adults) antibiotics, 6 - 13 days and 9-13, respectively; 11-14 and 7 days. For the duration of cefixime antibiotic treatment for children is 13 days. The results of this study indicate that antibiotics that are used effectively against typhoid fever patients are seen from the time of free of fever and length of stay.
\end{abstract}

Key words: Effectiveness, Antibiotics, Typhoid Fever, Children and adults

\begin{abstract}
Abstrak Untuk mengetahui efektifitas antibiotik pada pasien demam tifoid di SMF Ilmu Kesehatan Anak dan SMF Ilmu Penyakit Dalam RSUP Dr. M. Djamil Padang. Penelitian ini merupakan penelitian cross sectional dengan jenis data retrospektif selama tahun 2012 dan prospektif bulan Juni hingga September 2013, dengan disain analisa deskriptif. Jumlah pasien yang memenuhi kriteria inklusi sebanyak 11 pasien. Persentase penggunaan antibiotik pada pasien dewasa untuk seftriakson $(60 \%)$ dan kloramfenikol $(40 \%)$. Persentase penggunaan antibiotik pada pasien anak untuk seftriakson, kloramfenikol, dan sefiksim masing-masingnya adalah 60\%, 27\%, dan 13\%. Bebas demam untuk seftriakson dan kloramfenikol pada pasien anak dan dewasa, masing-masingnya adalah $2-3$ hari dan $4-6$ hari; 3 - 4 hari dan 4 hari. Untuk bebas demam sefiksim pada pasien anak adalah 2 hari. Lama rawatan yang dibutuhkan antibiotik seftriakson dan kloramfenikol (anak dan dewasa), masing-masingnya 6 - 13 hari dan 9 - 13; 11 -14 dan 7 hari. Untuk lama rawatan antibiotik sefiksim untuk anak adalah 13 hari. Hasil penelitian ini menunjukkan bahwa antibiotik yang digunakan efektif terhadap pasien demam tifoid dilihat dari waktu bebas demam dan lama rawatan.
\end{abstract}

Kata kunci : Efektifitas, Antibiotik, Demam tifoid, Anak, dan dewasa

\section{Introduction}

Demam tifoid merupakan infeksi sitemik yang disebabkan oleh bakteri Salmonella typhi, ia merupakan permasalahan kesehatan dunia. Kejadian demam tifoid di Indonesia digolongkan sebagai kejadian menengah. Centers for disease control and prevention melaporkan bahwa kejadian demam tifoid mencapai 358 hingga 810 per 100.000 populasi pada tahun 2007, dengan 64\% penyakit ditemukan pada usia 3 hingga 14 tahun dan angka mortilitas 3.1\% hingga 10\% pada pasien rawat inap (Medscape, 2013; Crump, 2004; CDC, 2013; Ochial et al, 2008; Mengo, 2010). Hasil survei di rumah sakit RSUP Dr. M. Djamil Padang menunjukkan bahwa demam tifoid menempati urutan kedua setelah gastroenteritis dan terdapat peningkatan dari tahun ke tahun (Nuzirwan, 1995).

Pada tahun 1948, untuk pertama kalinya antibiotik kloramfenikol digunakan sebagai terapi lini pertama untuk demam tifoid dan dapat menurunkan demam setelah 5 hari terapi dimulai. Dalam dua tahun, kloramfenikol dilaporkan telah resisten terhadap Salmonella typhi di Inggris akibat dari penggunaannya yang sembarangan. Dua dekade setelahnya, pada tahun 1972 untuk pertama kalinya dilaporkan kejadian 
multidrug resistant Salmonella typhi di Meksiko dan India. Sejak saat itu, resistensi kloramfenikol menjadi permasalahan besar di seluruh dunia. Tahun 1973 di Vietnam dan tahun 1977 di Korea dilaporkan kejadian resistensi kloramfenikol (Portnoy and Seah, 1979; Girgis, et al, 1999; Kalu, 2008; Kadhiravan, 2005).

Tahun 1975 di Prancis, telah dilaporkan adanya resistensi terhadap terapi alternatif untuk demam tifoid, yakni amoksisilin dan kotrimoksazol. Pada akhir tahun1980-an, Salmonella typhi dilaporkan telah resisten terhadap kloramfenikol, amoksisilin, dan kotrimoksazol. Kejadian Multidrug Resistant Salmonella typhi pertama sekali terjadi di Asia Tenggara pada tahun 1980-an dengan perkembangan yang terus terjadi. China pada tahun 1985, Pakistan pada tahun 1987, India (1988), Malaysia (1991), Singapura (1994), Bangladesh (1994), Vietnam (1995), Jepang (1999), Thailand (2001), Korea (2003), dan Indonesia terjadi pada tahun 2009 (Portnoy and Seah, 1979; Girgis, et al, 1999; Kalu, 2008; Kadhiravan, 2005).

Di Indonesia, kloramfenikol masih merupakan obat pilihan lini pertama untuk pengobatan demam tifoid pada anak. Namun, dalam beberapa tahun terakhir ini telah dilaporkan adanya multidrug resistant salmonella typhi. Sebelum tahun 2001, tingkat kejadian multidrug resistant di Sulawesi Tenggara masih rendah. Namun setelah tahun 2001, kejadian resistensi tersebut meningkat dengan meningkatnya kejadian demam tifoid (Hatta and Ratnawati, 2008). Dalam pengujian kerentanan antibiotik terhadap 8 jenis isolat Salmonella typhi yang ddiisolasi dari Surabaya diketahui bahwa semua isolat telah resisten terhadap asam nalidiksat dan amoksisilin. Selain itu, 3 dari 8 isolat tersebut juga menunjukkan resistensi ganda terhadap kloramfenikol, trimetoprim-sulfametoksazol dan siprofloksasin (Yanagi et al, 2009).

Untuk menghadapi perkembangan resistensi tersebut, badan kesehatan dunia (World Health Organization) pada tahun 2003 telah mempublikasikan pengobatan lini pertama terapi demam tifoid yang terbaru, yakni adalah antibiotik golongan florokuinolon (WHO, 2003). Handbook of Antimicrobial Therapy menggunakan antibiotik golongan florokuinolon atau seftriakson/sefotaksim sebagai terapi utama demam tifoid, dimana seftriakson/sefotaksim digunakan pada pasien anak dan florokuinolon digunakan untuk pasien dewasa (Abramowiez et al, 2011; BNF, 2011; BNFC, 2011).

Berdasarkan atas perkembangan pengobatan demam tifoid yang terjadi di dunia saat-saat ini dan berlandaskan dari salah satu sembilan Standar Kompetensi Apoteker Indonesia yang ditetapkan oleh Ikatan Apoteker Indonesia pada tanggal 15 Mei 2010 tersebut, yakni apoteker diharapkan mampu mengikuti perkembangan ilmu pengetahuan dan teknologi yang berhubungan dengan kefarmasian (IAI, 2010). Maka penulis sebagai apoteker merasa perlu untuk melakukan penelitian terhadap kajian efektifitas antibiotik pada pasien demam tifoid di SMF Ilmu Kesehatan Anak dan Ilmu Penyakit Dalam RSUP Dr. M. Djamil Padang.

Efektivitas antibiotik dapat terjadi dalam waktu singkat, yakni 3 hingga 5 hari, tetapi untuk status demam tifoid yang berat 10 hari juga dikatakan efektif. Terapi antibiotik golongan sefalosporin generasi ketiga dapat diberikan 10 hingga 14 hari (Dipiro et al, 2009; Kasper et al, 2005). Berdasarkan pedoman pengendalian demam tifoid yang dikeluarkan oleh Departemen Kesehatan Republik Indonesia tahun 2006 menyatakan bahwa penilaian efikasi antibiotik dinilai kurang lebih setelah 3 hingga 5 hari terapi, dimana pasien akan bebas demam pada hari ke-2 atau hari ke-3. Serta, lama rawatan yang dibutuhkan untuk pasien sampai dikatakan sembuh adalah 5 hingga 7 hari (Depkes, 2006). Oleh sebab inilah, maka 
efektifitas antibiotik pada penelitian ini didasarkan atas bebas demam dan lamanya hari rawatan di rumah sakit.

\section{The Methods}

Penelitian telah dilaksanakan selama 6 bulan (bulan Juni 2013 sampai bulan November 2013) di SMF Ilmu Kesehatan Anak dan SMF Ilmu Penyakit Dalam RSUP Dr. M. Djamil Padang. Penelitian ini merupakan studi cross sectional, yaitu penelitian yang dilakukan dengan cara observasi atau pengumpulan data sekaligus pada satu waktu, di rawat inap di SMF Ilmu Kesehatan Anak dan SMF Ilmu Penyakit Dalam RSUP Dr. M. Djamil Padang. Jenis data yang diambil adalah data pasien retrospektif pasien tahun 2012 dan data pasien prospektif selama empat bulan, yang dirawat inap di SMF Ilmu Kesehatan Anak dan di SMF Ilmu Pemyakit Dalam RSUP Dr. M. Djamil Padang. Sumber data berasal dari rekam medis pasien demam tifoid yang dirawat inap di SMF Ilmu Kesehatan Anak dan SMF Ilmu Penyakit Dalam RSUP Dr. M. Djamil Padang selama empat bulan penelitian dan data rekam medis pasien demam tifoid selama tahun 2012. Populasi adalah seluruh pasien demam tifoid yang terdapat di SMF Ilmu Kesehatan Anak dan SMF Ilmu Penyakit Dalam RSUP Dr. M. Djamil Padang. Sampel pada penelitian ini adalah semua sampel yang memenuhi kriteria dalam penelitian ini, yakni: Kriteria inklusi, Semua pasien demam tifoid tanpa komplikasi yang dirawat inap di SMF Ilmu Kesehatan Anak dan SMF Ilmu Penyakit Dalam RSUP Dr. M. Djamil Padang yang telah diizinkan pulang dengan izin dokter, memiliki data lengkap, memiliki pemeriksaan serologi, dan telah melakukan pemeriksaan leukosit minimal dua kali. Kriteria eksklusi: Pasien demam tifoid yang pulang paksa, pasien demam tifoid komplikasi, pasien demam tifoid yang meninggal dunia, pasien demam tifoid yang mengalami komplikasi, pasien pindah rawatan.

Efektivitas antibiotik dapat terjadi dalam waktu singkat, yakni 3 hingga 5 hari, tetapi untuk status demam tifoid yang berat 10 hari juga dikatakan efektif. Terapi antibiotik golongan sefalosporin generasi ketiga dapat diberikan 10 hingga 14 hari (Dipiro et al, 2009; Kasper et al, 2005). Berdasarkan pedoman pengendalian demam tifoid yang dikeluarkan oleh Departemen Kesehatan Republik Indonesia tahun 2006 menyatakan bahwa penilaian efikasi antibiotik dinilai kurang lebih setelah 3 hingga 5 hari terapi, dimana pasien akan bebas demam pada hari ke-2 atau hari ke-3. Serta, lama rawatan yang dibutuhkan untuk pasien sampai dikatakan sembuh adalah 5 hingga 7 hari (Depkes, 2006).

\section{Result and Discussion}

Perhitungan kuantitas antibiotik diperlukan untuk mengetahui antibiotik yang paling banyak digunakan untuk terapi demam tifoid pada pasien anak dan pasien dewasa yang menjalani rawat inap di RSUP Dr. M. Djamil Padang. Dari hasil observasi terhadap pasien demam tifoid anak di SMF Ilmu Kesehatan Anak ternyata didapatkan persentase penggunaan antibiotik pada pasien anak untuk seftriakson (40\%), kloramfenikol (15\%), sefiksim (15\%), trimetoprim-sulfametoksazol (15), sefadroksil (8\%) dan tiamfenikol (7\%). Jumlah kasus penggunaan antibiotik pada pasien demam tifoid dewasa di SMF Ilmu Penyakit Dalam RSUP Dr. M. Djamil Padang, yakni: 60\% untuk antibiotik seftriakson dan 40\% untuk antibiotik kloramfenikol.

\section{Profil penggunaan antibiotik}


Tabel 5 menunjukkan bahwa terdapat tiga jenis antibiotik yang digunakan untuk pasien demam tifoid anak di SMF Ilmu kesehatan Anak RSUP Dr. M. Djamil Padang yang terdiri dari golongan kloramfenikol, golongan sefalosporin, dan golongan sulfonamid.

Tabel 5. Jenis antibiotik yang digunakan pada pasien demam tifoid anak di SMF Ilmu Kesehatan Anak RSUP Dr. M. Djamil Padang

\begin{tabular}{|l|c|c|r|}
\hline \multicolumn{5}{|c|}{ ANTIBI0TIK } \\
\hline Nloramfenikol & Tablet & Peroral & $\begin{array}{r}\text { 4x250mg } \\
4 \times 500 \mathrm{mg}\end{array}$ \\
\hline Tiamfenikol & Tablet & Peroral & $3 \times 500 \mathrm{mg}$ \\
\hline Sefadroksil & Sirup & Peroral & $2 \times 187.5 \mathrm{mg}$ \\
\hline Sefiksim & Kapsul & Peroral & $2 \times 50 \mathrm{mg}$ \\
& & & $2 \times 150 \mathrm{mg}$ \\
\hline Seftriakson & Injeksi & iv & $2 \times 500 \mathrm{mg}$ \\
& & & $2 \times 600 \mathrm{mg}$ \\
& & & $2 \times 1 \mathrm{~g}$ \\
& & & $2 \times 1250$ \\
& & & $\mathrm{mg}$ \\
\hline Trimetoprin- & Tablet & Peroral & $2 \times 720 \mathrm{mg}$ \\
Sulfametoksasol & & & $2 \times 50 \mathrm{mg}$ \\
\hline
\end{tabular}

Tabel 6 menunjukkan bahwa terdapat dua golongan antibiotik yang digunakan untuk pasien demam tifoid dewasa di SMF Ilmu Penyakit Dalam RSUP Dr. M. Djamil Padang yang terdiri dari golongan sefalosporin dan golongan kloramfenikol.

Tabel 6. Jenis antibiotik yang digunakan pada pasien rawat inap demam tifoid dewasa di SMF Ilmu Penyakit Dalam RSUP Dr. M. Djamil Padang

\begin{tabular}{|c|c|c|c|}
\hline \multicolumn{4}{|c|}{ ANTIBIOTIK } \\
\hline \multicolumn{1}{|c|}{ NAMA } & SEDIAAN & RUTE & DOSIS \\
\hline Seftriakson & Injeksi & Intravena & $2 \times 1 \mathrm{~g}$ \\
\hline Kloramfenikol & Tablet & Peroral & $4 \times 250 \mathrm{mg}$ \\
\hline
\end{tabular}

Pengaruh antibiotik seftriakson terhadap waktu bebas demam, pemeriksaan leukosit, dan lama rawatan pada pasien demam tifoid anak di SMF Ilmu Kesehatan Anak RSUP Dr. M. Djamil Padang.

Berdasarkan hasil pengamatan yang telah dilakukan pada empat kasus antibiotik seftriakson tunggal (Gambar 8, 9, 10 dan 11) pada pasien demam tifoid anak di RSUP Dr. M. Djamil ternyata diperoleh hari bebas demam dicapai pada hari kedua setelah terapi dilakukan. Suhu tubuh yang tercatat pada saat pertama kali datang ke rumah sakit berada pada keadaan yang demam, kecuali pada kasus pasien anak PA 7 (Gambar 10). Pada pasien PA 8, suhu tubuh pasien anak kembali demam saat hari ketujuh dan 
kedelapan rawatan dan pada hari kesembilan kembali bebas demam hingga pasien diizinkan untuk pulang.

Hasil pemeriksaan leukosit pertama kali pada tiga kasus yang ada (Gambar 8, 9 dan 11) adalah normal. Berbeda dengan kasus pasien anak PA 7 (Gambar 10) yang mengalami leukositosis. Dihari kedua pemeriksaan leukosit, pasien anak PA 7 tetap mengalami leukositosis tetapi tidak dengan pasien anak PA 5 dan PA 6. Pemeriksaan leukosit normal ternyata tercatat pada hari ketiga dan hari keenam rawatan untuk pasien anak PA 7. Untuk pemeriksaan ulang leukosit pasien anak PA 8 adalah normal.

Lama rawatan yang dibutuhkan antibiotik seftriakson untuk masing-masing pasien anak PA 5, PA 6, PA 7, dan PA 8 adalah enam, tujuh, enam, dan dua belas hari.

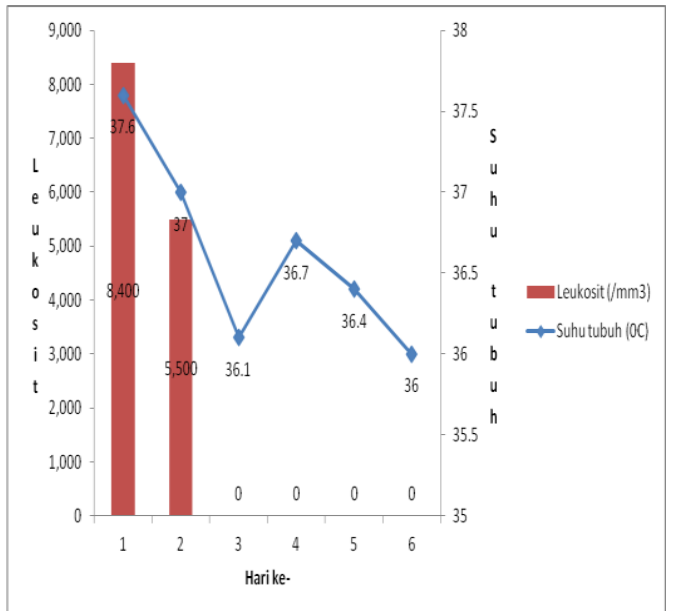

Gambar 8. Pengaruh antibiotik seftriakson terhadap waktu bebas demam, pemeriksaan leukosit, dan lama rawatan pada pasien demam tifoid anak PA 5

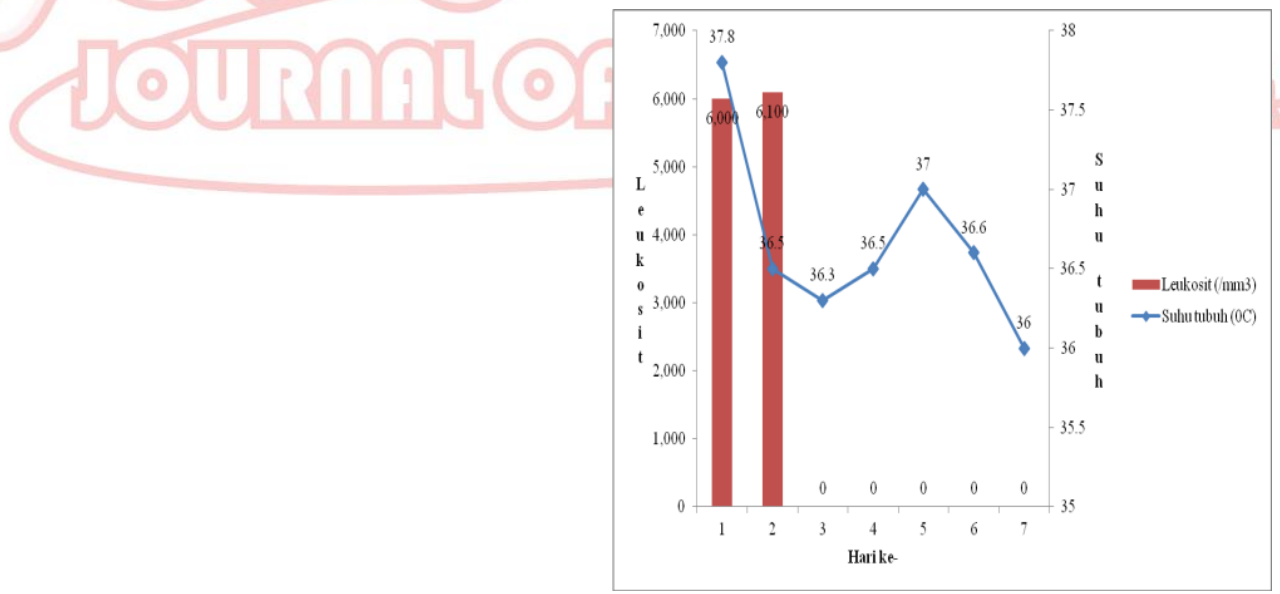

Gambar 9. Pengaruh antibiotik seftriakson terhadap waktu bebas demam, pemeriksaan leukosit, dan lama rawatan pada pasien demam tifoid anak PA 6 


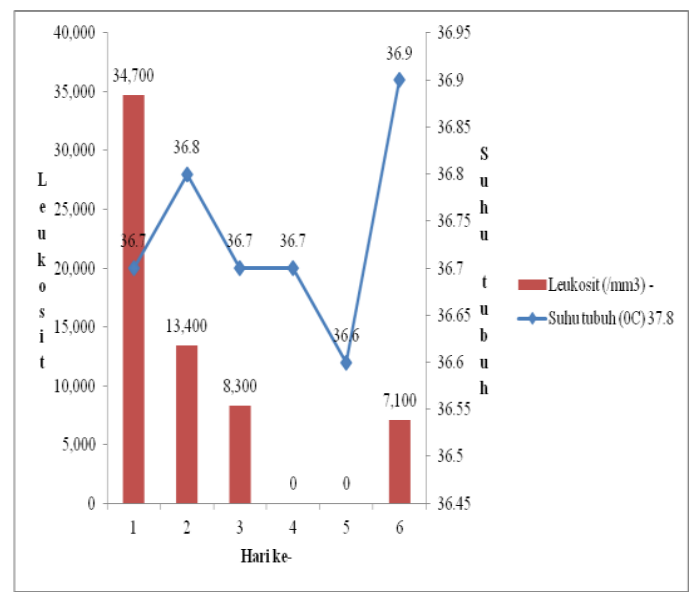

Gambar 10. Pengaruh antibiotik seftriakson terhadap waktu bebas demam, pemeriksaan leukosit, dan lama rawatan pada pasien demam tifoid anak PA 7

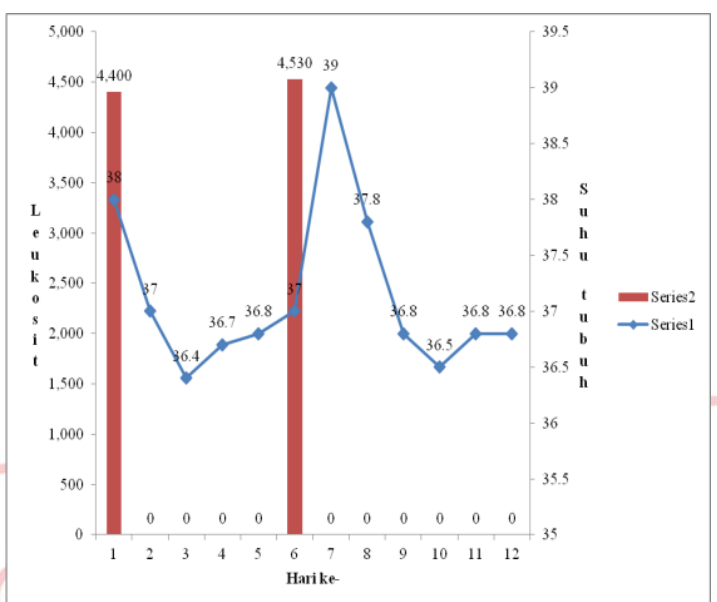

Gambar 11. Pengaruh antibiotik seftriakson terhadap waktu bebas demam, pemeriksaan leukosit, dan lama rawatan pada pasien demam tifoid anak PA 8

Pengaruh antibiotik kloramfenikol terhadap waktu bebas demam, pemeriksaan leukosit, dan lama rawatan pada pasien demam tifoid anak di SMF Ilmu Kesehatan Anak RSUP Dr. M. Djamil Padang

Bebas demam yang terjadi pada terapi antibiotik kloramfenikol terjadi pada hari kedua setelah pemberian terapi (Gambar 12). Hasil pemeriksaan leukosit pada dua kali pemeriksaan menunjukkan nilai normal untuk kedua kasus yang ada. Lama rawatan yang dibutuhkan adalah empat belas hari. 


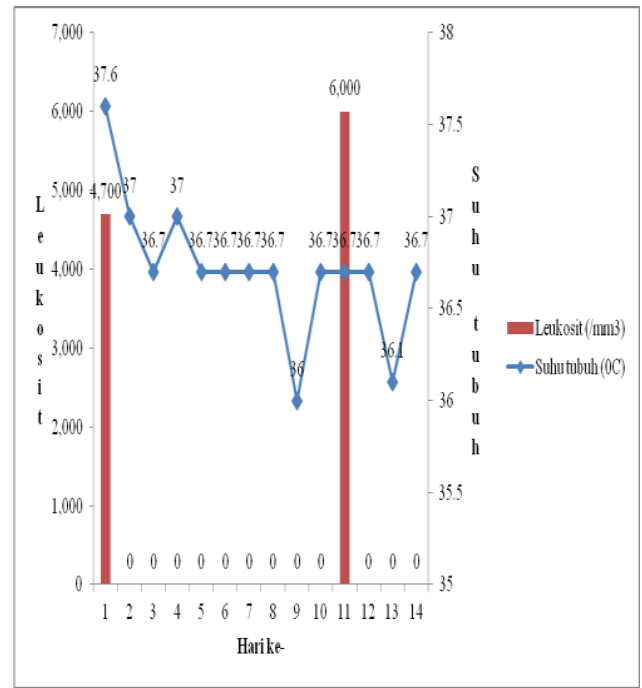

Gambar 12. Pengaruh antibiotik kloramfenikol terhadap waktu bebas demam, pemeriksaa leukosit, dan lama rawatan pada pasien demam tifoid anak PA 1

Pengaruh antibiotik tiamfenikol terhadap waktu bebas demam, pemeriksaan leukosit, dan lama rawatan pada pasien demam tifoid anak di SMF Ilmu Kesehatan Anak RSUP Dr. M. Djamil Padang

Pada pasien anak PA 4 ini didapatkan hari bebas demam adalah hari kelima dengan pencatatan suhu adalah $36.4^{\circ} \mathrm{C}$. Suhu tubuh awal masuk adalah $38.8^{\circ} \mathrm{C}$ dan hasil pemeriksaan leukosit adalah $3.500 / \mathrm{mm}^{3}$. Lama rawatan yang terjadi adalah sebelas hari.

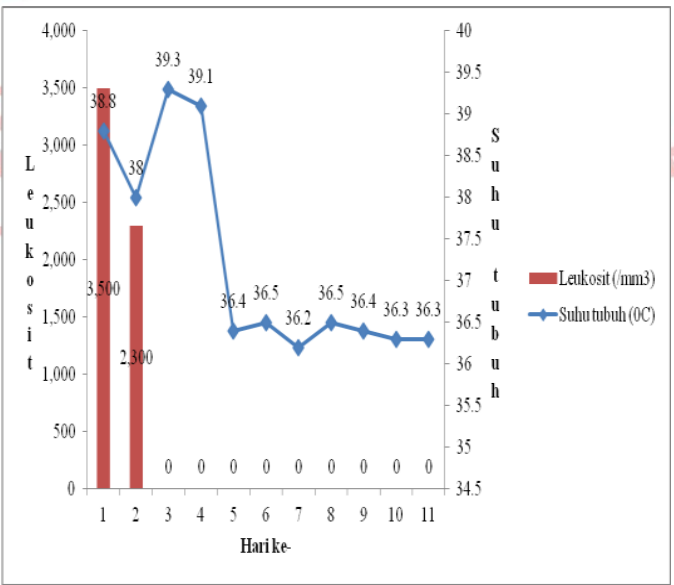

Gambar 13. Pengaruh antibiotik tiamfenikol terhadap waktu bebas demam, pemeriksaan leukosit, dan lama rawatan pada pasien demam tifoid anak PA 4

Pengaruh pergantian antibiotik terhadap waktu bebas demam, pemeriksaan leukosit, dan lama rawatan pada pasien demam tifoid anak di SMF Ilmu Kesehatan Anak RSUP Dr. M. Djamil Padang

Untuk kasus pasien anak PA 2 dan PA 3 (Gambar 14 dan 15), didapatkan ternyata terapi antibiotik yang diterima bukanlah terapi tunggal selama masa rawatan. Berbagai golongan antibiotik telah diterima. Untuk kasus anak PA 2 (Gambar 14) terjadi tiga kali pergantian antibiotik. Untuk hari pertama hingga 
hari ketiga, pasien menerima antibiotik sefadroksil. Hari keempat hingga hari kesepuluh, pasien menerima terapi antibiotik sanprima (kotrimoksazol). Hari kesebelas menerima terapi kombinasi sanprima (kotrimoksazol) dengan sefiksim. Namun, dihari kedua belas hingga tiga belas pasien menerima terapi sefiksim saja.

Pasien anak PA 2 ternyata masih mengalami demam hingga hari ketujuh rawatan meskipun pada hari kedua dan keempat suhu tubuh sempat normal. Suhu tubuh secara tetap mengalami bebas demam pada hari kedelapan rawatan hingga hari ketiga belas pasien diizinkan pulang. Hasil pemeriksaan leukosit yang dilakukan sebanyak dua kali, hari pertama dan hari kesebelas, masing-masingnya adalah normal.

Hal yang sama ternyata juga ditemukan pada pasien anak PA 3 (Gambar 15). Empat jenis antibiotik telah digunakan. Hari pertama hingga hari ketiga, menerima terapi kotrimoksazol dan kandistatin. Hari keempat hingga hari keenam, kotrimoksazol digantikan dengan kloramfenikol. Hari ketujuh hingga hari kesepuluh, kloramfenikol digantikan dengan sefiksim. Hari kesebelas, pemberian kandistatin dihentikan dan sefiksim digantikan dengan seftriakson, hingga hari ketiga belas saat pasien diizinkan pulang.

Sebanyak tiga kali pemeriksaan leuksoit pada pasien anak PA 3 ini, diketahui ternyata pada hari pertama rawatan pasien mengalami leukositosis dan pada hari keenam serta hari kesepuluh, hasil pemeriksaan leukosit adalah normal. Dari hari pertama hingga hari kesepuluh, hanya hari kedua rawatan yang bebas demam. Mulai dari hari kesebelas hingga hari ketiga belas pasien anak PA 3 mengalami bebas demam.

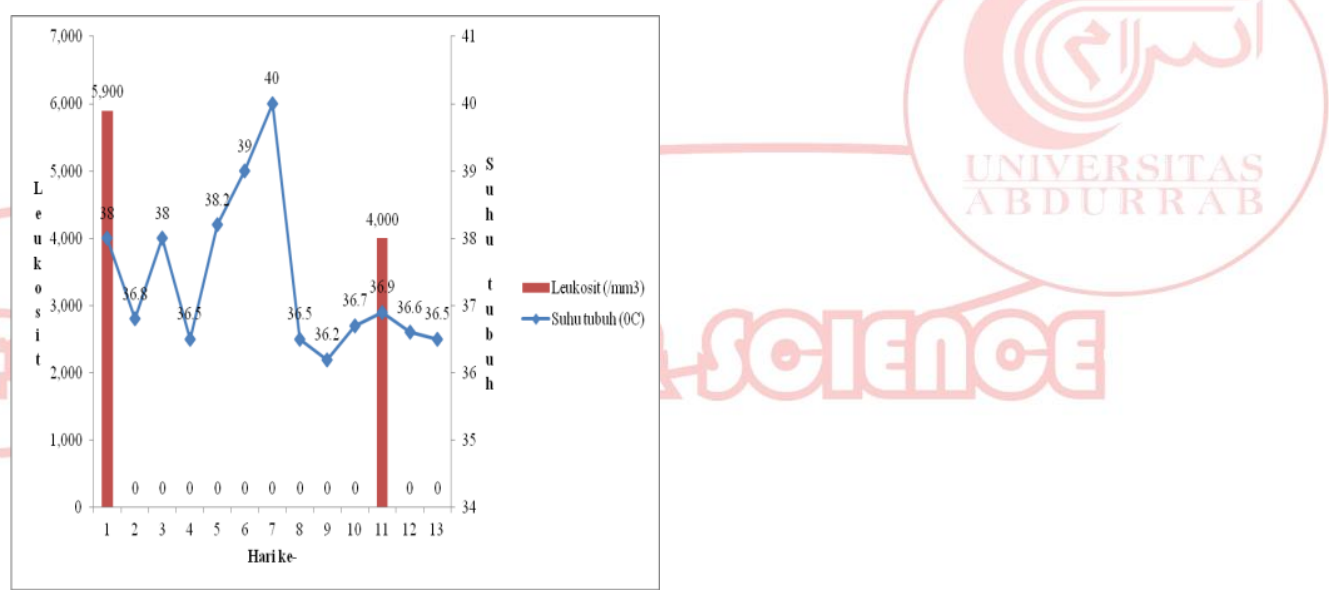

Gambar 14. Pengaruh pergantian antibiotik terhadap waktu bebas demam, pemeriksaan leukosit, dan lama rawatan pada pasien demam tifoid anak PA 2

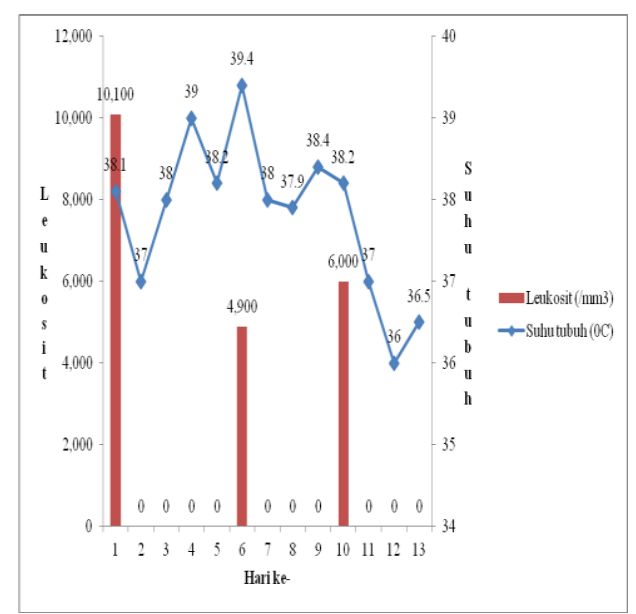


Gambar 15. Pengaruh pergantian antibiotik terhadap waktu bebas demam, pemeriksaan leukosit, dan lama rawatan pada pasien demam tifoid anak PA 3

Pengaruh antibiotik seftriakson terhadap waktu bebas demam, pemeriksaan leukosit, dan lama rawatan pada pasien demam tifoid dewasa di SMF Ilmu Penyakit Dalam RSUP Dr. M. Djamil Padang

Pada penelitian ini didapatkan bahwa untuk terapi antibiotik seftriakson, bebas demam terjadi pada hari kelima hingga hari keenam, dengan lama rawatan selama sembilan hingga tiga belas hari. Hasil pemeriksaan leukosit pada hari pertama adalah normal. Untuk pemeriksaan kedua, hasil pemeriksaan leukosit tetap normal.
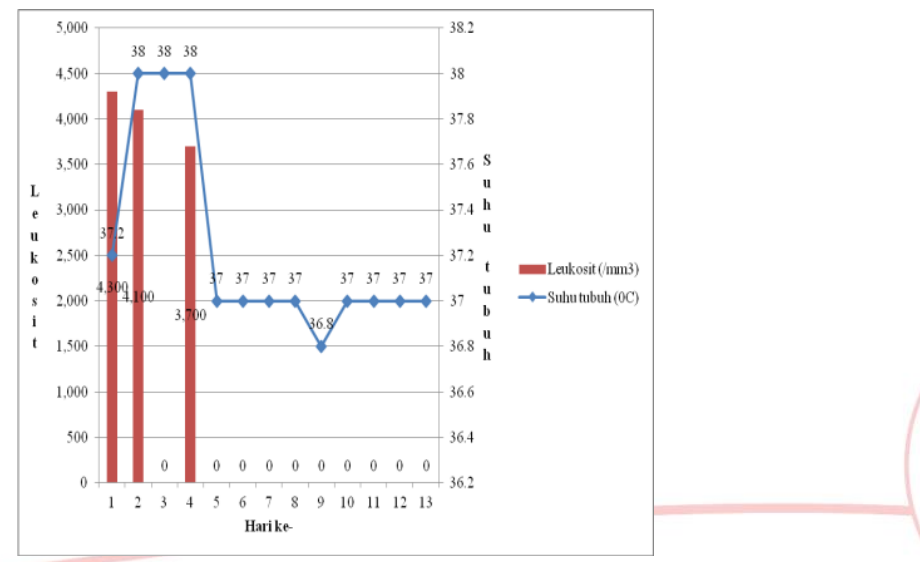

Gambar 16. Pengaruh antibitoik seftriakson terhadap bebas demam, pemeriksaan leukosit dan lama rawatan pada pasien demam tifoid dewasa PD 1

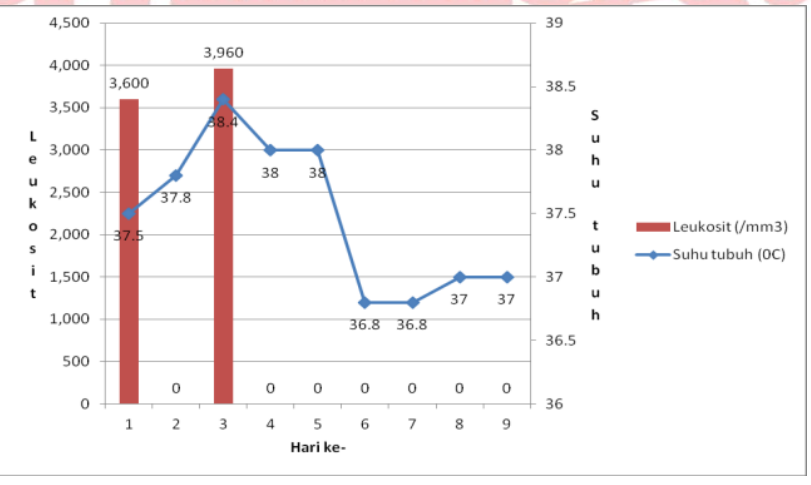

Gambar 17. Pengaruh antibiotik seftriakson terhadap waktu bebas demam, pemeriksaan leukosit dan lama rawatan pada pasien demam tifoid dewasa PD 3

Pengaruh antibiotik kloramfenikol terhadap waktu bebas demam, pemeriksaan leukosit, dan lama rawatan pada pasien demam tifoid dewasa di SMF Ilmu Penyakit Dalam RSUP Dr. M. Djamil Padang 
Untuk antibiotik kloramfenikol pada pasien dema tifoid dewasa, didapatkan hari bebas demam terjadi pada hari ketiga setelah terapi dimulai. Lama rawatan yang dibutuhkan adalah enam hari. Pasien mengalami leukositosis pada hari ketiga setelah terapi. Semantara pada hari pertama dan kelima, hasil pemeriksaan leukosit adalah normal (Gambar 18).

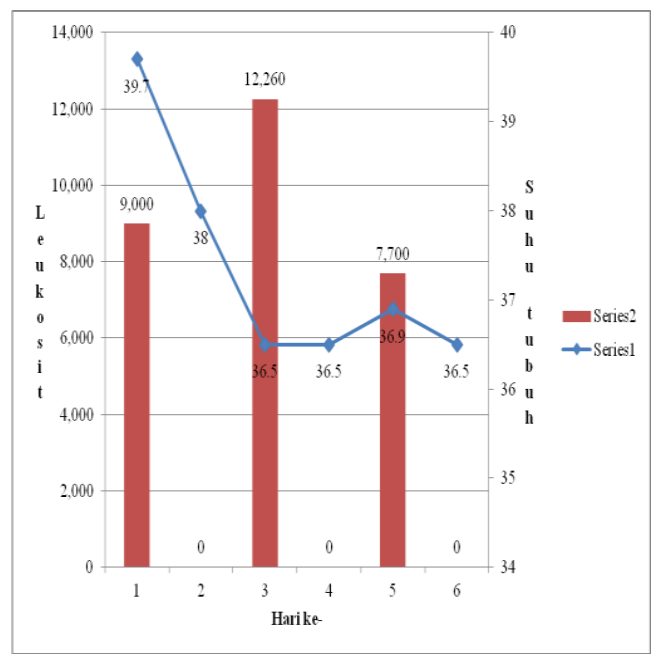

Gambar 18. Pengaruh antibiotik kloramfenikol terhadap waktu bebas demam, pemeriksaan leukosit dan lama rawatan pada pasien demam tifoid dewasa PD 2

\section{DISCUSSION}

\section{Perolehan sampel}

Dari 92 jumlah populasi retrospektif selama tahun 2012 dan prospektif selama empat bulan di tahun

2013 yang telah terkumpul, ternyata yang memenuhi kriteria inklusi dan eksklusi untuk jumlah sampel retrospektif adalah 10 pasien dengan rincian, yaitu: 2 pasien dewasa dan 8 pasien anak. Sementara, untuk jumlah sampel prospektif adalah 1 pasien dewasa. Sedikitnya jumlah perolehan sampel yang didapat pada penelitian ini disebabkan karena salah satu kriteria inklusi yang harus dipenuhi tidak banyak ditemukan. Kriteria tersebut adalah pemeriksaan leukosit lebih dari satu kali.

Hubungan antara perilaku higiene perseorang dengan kejadian demam tifoid mungkin dapat menjelaskan bagaimana pasien anak bisa lebih banyak dari pada pasien dewasa pada penelitian ini. Perilaku higiene tersebut diataranya: mencuci tangan sebelum makan, mencuci tangan setelah buang air besar, minum air matang, mengkonsumsi makanan matang, mencuci buah dan sayuran sebelum dikonsumsi dan menggunakan alat makan yang bersih (Masitoh, 2009). Hal-hal teresbutlah yang jarang diperhatikan secara khusus pada pasien anak-anak sehingga menyebabkan anak-anak akan lebih rentan terkena infeksi.

Menurut pencatatan yang dilakukan World Health Organization pada tahun 2003, sebanyak 90\% pasien demam tifoid merupakan pasien rawat jalan (WHO, 2003). Kasus demam tifoid dilaporkan sebagai penyakit endemis di negara berkembang, yakni 95\% merupakan kasus rawat jalan (Parry et al, 2002). Ternyata hal tersebut tidak ditemukan pada penelitian ini, jumlah pasien rawat inap lebih banyak dari pada pasien rawat jalan. Jumlah pasien rawat inap untuk tahun 2012 adalah sebanyak 91 pasien, sementara jumlah pasien rawat jalan di tahun 2012 adalah 25 pasien. Hal ini mungkin disebabkan karena 
diagnosa banding yang dimiliki demam tifoid yang menjadi penyulit dalam mendiagnosa pasien rawat jalan di RSUP Dr M. Djamil Padang, seperti demam berdarah dan malaria, bila diagnosis tidak dapat dilakukan secara tepat. Diagnosa bandingan tersebut juga didukung dengan ditetapkannya Provinsi Sumatera Barat, Kota Padang, sebagai daerah endemik keduanya (Depkes 2010; Depkes, 2011).

\section{Kualitas dan profil penggunaan antibiotik}

Konsentrasi suatu antibiotik pada tempat infeksi haruslah mencukupi untuk menghambat atau memusnahkan mikroorganisme penyebab infeksi. Kesesuai antibiotik yang diterima pasien demam tifoid anak di SMF Ilmu Kesehatan Anak dan pasien dewasa SMF Ilmu Penyakit Dalam terhadap rekomendasi yang diberikan oleh Departemen Kesehatan Republik Indonesia ternyata ditemukan pada pasien anak PA 2 untuk kotrimoksazol, kloramfenikol untuk pasien anak PA 3 (Lampiran 4, Tabel 12), serta pasien dewasa PD 1 dan PD 3 untuk seftriakson (Lampiran 5, Tabel 13). Namun, pada penelitian ini juga ditemukan adanya pemberian dosis yang kurang. Hal tersebut terjadi pada pasien anak PA 1 untuk terapi kloramfenikol dan PA 2 untuk terapi sefiksim (Lampiran 4, Tabel 12), serta pasien dewasa PD 2 yang menerima antibiotik kloramfenikol (Lampiran 5, Tabel 13).

Dosis yang melebihi rekomendasi untuk terapi tifoid ternyata ditemukan pada penelitian ini. Kejadian tersebut terjadi pada pasien anak PA 3 untuk terapi seftriakson, PA 4 untuk terapi tiamfenikol, PA 3 untuk terapi sefiksim, dan PA 3 untuk terapi kotrimoksazol (Lampiran 4, Tabel 12). Antibiotik yang tidak mecapai targetnya karena konsentrasi di serum yang kurang mengakibtkan kegagalan terapi dan bahakan timbulnya resistensi bakteri Salmonella typhi terhadap antibiotik. Konsentrasi antibiotik pada tempat infeksi hendaknya tidak hanya mampu menghambat mikroorganisme tersebut, namun juga harus tetap di bawah kadar toksiknya terhadap sel mamalia (Gillman et al, 2008).

\section{Pengaruh antibiotik terhadap waktu bebas demam, hasil pemeriksaan leukosit, dan lama rawatan} pada pasien demam tifoid

a. Antibiotik terhadap waktu bebas demam

Mengetahui hasil penelitian yang telah didapatkan mengenai waktu bebas demam yang diperoleh oleh antibiotik seftriakson pada empat kasus pasien demam tifoid anak dan dewasa yang ada ternyata sejalan dengan hasil penelitian yang pernah dilakukan sebelumnya, dimana untuk waktu bebas demam antibiotik seftriakson pasien anak yang dibutuhkan adalah 5.2 hari (Tatli et al, 2003) dan untuk pasien demam tifoid dewasa dibutuhkan waktu bebas demam 3.3 hari (Hammad et al, 2011).

Untuk antibiotik kloramfenikol pasien demam tifoid anak dan dewasa di penelitian ini ternyata masingmasingnya adalah 2 hari dan 3 hari. Sementara untuk antibiotik tiamfenikol, waktu bebas demam yang dibutuhkan adalah 5 hari. Hal yang didapatkan ini ternyata jauh lebih baik dibandingkan dengan hasil penelitian yang telah dilakukan oleh Tatli dan rekan yang mendapatkan rata-rata hari bebas demam yang dibutuhkan untuk antibiotik kloramfenikol adalah 2 hari (Tatli et al, 2003) serta yang telah dilakukan oleh Hammad pada tahun 2011, didatkan waktu bebas demam untuk pasien demam tifoid dan dewasa adalah 5.8 hari (Hammad at al, 2011). Beberapa teori juga telah menjelaskan bahwa waktu bebas demam yang terjadi pada pasien dewasa yang menerima terapi kloramfenikol adalah 4 hingga 5 hari (Sudoyo dkk, 1996). Dan lama rawatan pasien dewasa untuk kloramfenikol adalah 10 (Chowta and Chowta, 2005). 
Tidak adanya perbaikan dari gejala dan tanda serta diperlukannya pergantian terapi antibiotik merupakan suatu kegagalan dalam terapi (Butlet et al, 1999; Islam et al, 1993). Untuk kloramfenikol yang diberikan pada pasien anak PA 3, antibiotik tersebut telah gagal menurunkann suhu tubuh pasien selama tiga hari pemberian, sehingga membuat terapi kloramfenikol digantikan dengan antibiotik sefiksim. Hal yang sama juga terjadi pada pasien anak PA 2 dan PA 3 yang telah menerima terapi antibiotik kotrimoksazol. Kotrimoksazol gagal dalam membebas demamkan pasien sehingga mengakibatkan terapi antibitok mengalami pergantian.

Tujuan utama dari pasien rawatan demam tifoid di rumah sakit ialah untuk mengoptimalisasi pengobatan dan mempercepat penyembuhan (Depkes, 2006). Tujuan tersebut sepertinya tidak dilaksanakan pada pasien anak PA 4 dan pasien PD 3. Kedua pasien ini tidak mendaptkan terapi antibiotik pada saat hari pertama di rawat di SMF Ilmu Kesehatan Anak dan SMF Ilmu Penyakit Dalam RSUP Dr. M. Djamil Padang. Selama hari rawatan tanpa antibiotik tersebut, terapi yang diberikan adalah parasetamol sebagai antipiretik dan vitamin. Keterlambatan pemberian antibiotik pernah terjadi pada seorang pria kebangsaan jepang yang datang dengan keluhan nyeri perut, muntah, dan demam saat malam hari, $38.88^{\circ} \mathrm{C}$. Pasien mendapatkan terapi cairan infus, analgetik, omeprazol dan parasetamol. Pasien tetap demam setelah dua hari rawatan. Hari berikutnya, diketahui bahwa hasil biakan darah meningkat terhadap Salmonella typhi yang sensitif terhadap siprofloksasin. Setalah 3 hari pemberian antibiotik tersebut, demam secara bertahap menjadi normal (Thapa, 2010).

Pemilihan antibiotik sefadroksil untuk pasien anak PA 2 dirasakan tidak tepat karena tidak sesuai dengan yang telah direkomenadasi World Health Organization dan Departemen Kesehatan Republik Indonesia, bahwa antibiotik sefalosporin yang digunakan adalah sefalosporin generasi ketiga (WHO, 2003; Depkes, 2006). Hal tersebut disebabkan karena sefadroksil yang merupakan sefalosporin generasi I yang memiliki aktivitas lebih baik terhadap bakteri gram positif dari pada gram negatif. Oleh sebab itu, Salmonella typhi yang merupakan bakteri gram negatif lebih rentan terhadap sefalosporin generasi ketiga karena sefalosporin generasi ketiga lebih efektif terhadap bakteri gram negatif dari pada bakteri gram positif (Katzung et al, 2009).

Pada kasus anak PA 8 yang menerima terapi antibiotik seftriakson (Gambar 11), didapatkan pasien mengalami demam kembali pada hari ketujuh dan kedelapan, dan setelah itu pasien kembali bebas demam hingga diizinkan untuk pulang. Menurut hasil terapi empiris yang telah dilakukan, didaptkan bahwa terapi seftriakson akan menunjukkan perbaikan klinis pada pasien demam tifoid anak selama 3 hingga 5 hari setelah terapi (Depkes, 2006). Pasien dikatakan kambuh apabila pasien mengalami demam kembali setelah menyelesaikan pengobatan terapi antibiotik (WHO, 2003). Jadi, mungkin bisa diperkirakan bahwa pasien telah mengalami kekambuhan demam tifoid.

\section{b. Antibiotik terhadap lama rawatan}

Lama rawatan yang dibutuhkan pasien demam tifoid untuk dirawat di rumah sakit dan diizinkan untuk dapat pulang menurut Departeman Kesehatan adalah 5 hingga 7 hari, dengan persyaratan pulang adalah 5 hingga 7 hari telah bebas demam dan keadaan umum membaik (Depkes, 2006). Pada penelitian ini ternyata didapatkan bahwa lama rawatan yang dibutuhkan antibiotik seftriakson pada pasien anak adalah 6 hingga 13 hari, sementara untuk pasien dewasa adalah 9 hingga 13 hari. Untuk antibiotik 
kloramfenikol, dibutuhkan lama rawatan selama 11 hingga 14 hari pada pasien anak dan 7 hari untuk pasien dewasa. Antibiotik kloramfenikol dapat diberikan selama empat belas hingga dua puluh satu hari (Depkes RI, 2006; WHO, 2003; Kundu et al, 2006). Terapi antibiotik golongan sefalosporin generasi ketiga dapat diberikan selama 10 hingga 14 hari (Kasper et al, 2005). Lama rawatan yang dibutuhkan untuk terapi seftriakson adalah 4.408 hari (Musnelina dkk, 2004).

Salah satu faktor yang menyebabkan dibutuhkannya waktu yang lama untuk pasien demam tifoid di rawat di rumah sakit adalah kegagalan terapi antibiotik yang dapat menurunkan demam pasien, sehingga menyebabkan pasien tersebut menerima pergantian terapi golongan antibiotik yang lain dari terapi awal. Hal tersebut terjadi pada pasien anak PA 2 dan PA 3. Tidak adanya perbaikan dari gejala dan tanda serta diperlukannya pergantian terapi antibiotik merupakan suatu kegagalan dalam terapi antibiotik demam tifoid (Butlet et al, 1999; Islam et al, 1993).

\section{c. Antibiotik terhadap hasil pemeriksaan leukosit}

Leukosit merupakan unit bergerak aktif dari sistem pertahan tubuh terhadap setiap bahan infeksius yang datang, bakteri sehingga terjadi penyerangan dan penghancuran bakteri tersebut dengan cara meningkatkan jumlahnya tempat hingga lima kali jumlah normlanya atau lebih sering disebut leukositosis kejadian tersebut (Guyton and Hall, 2007). Oleh karena demam tifoid disebabkan oleh infeksi bakteri Salmonella typhi maka tentu hasil pemeriksaan leukosit yang dilakukan saat pertama kali datang adalah meningkat atau leukositosis. Kejadian tersebut ternyata hanya terjadi pada pasien anak PA 3 dan PA 7 yang masing-masing hasil pemeriksaaannya adalah $10.100 / \mathrm{mm}^{3}$ dan $34.000 / \mathrm{mm}^{3}$, selebihnya memiliki hasil pemeriksaan yang normal. Hal tersebut ternyata juga telah pernah diteliti oleh Islam dan rekan dalam penelitian yang berjudul treatment of typhoid fever with ceftriaxone for 5 days or chloramphenicol for 14 days: a randomized clinical trial dimana diketahui bahwa hasil pemeriksaan leukosit untuk pasien demam tifoid adalah $3.000 / \mathrm{mm}^{3}$ hingga $21.600 / \mathrm{mm}^{3}$ untuk kedua kelompok terapi (Islam et al, 1993). Hasil pemeriksaan leuksoit pasien demam tifoid sebelum menerima terapi antibiotik berada pada range $2.400 / \mathrm{mm}^{3}$ hingga $12.000 / \mathrm{mm}^{3}$ (Smith et al, 1994).

Setelah menerima terapi antibiotik dan beberapa terapi simptomatik lainnya, hasil pemeriksaan leukosit kembali dilakukan. Dari semua pasien demam tifoid anak yang telah diperiksa ternyata hanya ada satu pasien anak yang masih mengalami leukositosis, yakni pasien anak PA 7 yang menerima terapi seftriakson dan selebihnya telah menunjukkan hasil yang normal. Hasil pemeriksaan leukosit yang normal pada pasien anak PA7 terjadi pada hari ketiga. Pada kasus PA 7 juga diketahui ternyata dengan hasil pemeriksaan leukosit yang tinggi tidak mempengaruhi suhu tubuh pasien untuk menjadi demam. Sementara itu, untuk pasien dewasa diketahui bahwa hasil pemeriksaan leukosit yang meningkat terjadi pada pasien dewasa PD 2 yang menerima terapi kloramfenikol (Gambar 18) dan untuk sisanya adalah normal. Berdasarkan hasil penelitian yang telah dilakukan pada pasien anak dan dewasa terapi antibiotik kloramfenikol dan seftriakson, didapatkan hasil pemeriksaan leukosit terapi seftriakson pada hari kelima adalah $4.500 / \mathrm{mm}^{3}$ hingga $16.600 / \mathrm{mm}^{3}$ dan untuk terapi kloramfenikol adalah $5.000 / \mathrm{mm}^{3}$ hingga $19.000 / \mathrm{mm}^{3}$ untuk kelompok terapi kloramfenikol (Islam et al, 1993).

\section{Peran apoteker dalam pelayanan farmasi di rumah sakit}


Melihat kenyataan yang terjadi pada penelitian ini, yakni didapatkan dosis antibiotik yang diterima pasien masih ada yang lebih atau bahkan kurang dari terapi yang direkomendasikan di RSUP Dr. M. Djmail Padang. Maka diperlukan adanya pelayanan farmasi di rumah sakit. Pelayanan farmasi rumah sakit adalah bagian yang tidak terpisahkan dari sistem pelayanan kesehatan rumsah sakit yang berorientasi kepada pelayanan pasien. Dalam tuntutan pasien dan masyarakat akan mutu pelayanan farmasi, mengharuskan adanya perubahan paradigma pelayanan dari paradigma lama drug oriented ke paradigma baru patient oriented yang mengacu kepada pelayanan kefarmasian. Sebagai konseksuensi perubahan orientasi tersebut, apoteker dituntun untuk untuk meningkatkan pengetahuan, keterampilan, dan perilaku sehingga dapat berkomunikasi secara langsung yang tidak hanya dengan pasien namun juga dengan tenaga kesehatan lainnya (Menkes, 2004).

Sejalan dengan program World Health Organization/WHO, Indonesia sebagai bagian dari komunitas dunia berkomitmen untuk mengamankan antibiotik untuk generasi selanjutnya. Sebagai bagian dari pelayanan kesehatan, pelayanan kefarmasian turut berkontribusi dalam usaha menghambat resistensi.

Pelayanan Kefarmasian yang dilakukan oleh Apoteker terkait terapi antibiotik, dalam mewujudkan terapi antibiotik yang bijak dan pencegahan resistensi, hendaknya dilakukan secara bertanggung jawab sehingga kualitas hidup pasien meningkat. Untuk dapat meningkatkan kualitas pelayanan kefarmasian, Apoteker perlu meningkatkan ketrampilan, sikap dan pengetahuan secara berkesinambungan sejalan dengan perkembangan terkini (Menkes, 2011). Bila hal tersebut dapat terealisasikan dengan baik dan terbentuk integrasi yang terpadu antara apoteker dan tenaga kesehatan lainnya. Maka kualitas pelayanan kesehatan dapat ditingkatkan ke arah yang lebih baik lagi.

\section{Conclusion}

Berdasarkan hasil penelitian yang telah dilakukan di SMF Ilmu Penyakit Dalam dan SMF Ilmu Kesehatan Anak RSUP Dr. M. Djamil Padang, maka dapat disimpulkan bahwa antibiotik yang digunakan efektif terhadap pasien demam tifoid dilihat dari waktu bebas demam dan lama rawatan.

\section{References}

Abramowiez, M., G. Zuccotti., J. M. Pflomn., S. M. Daron., B. M. Houst., C. e. Zanone and B. M. Shah. 2011. Handbook Of AntimicrobialTherapy. 19 $9^{\text {th }}$ Edition. The Medical Letter Inc: New York

Bajaracharya, B.L., Baral M.R., Shakya, S., Tuladhar, P., Paudel, M and Acharya. 2006. Clinical Profile And Antibiotics Response In Typhoid Fever. Kathmandu University Medical Journal. Original Article. 4: 1

Behrman, R. E., Kliegmam, R. M. and Arvin, A. M. 1999. Ilmu Kesehatan Anak Nelson. Edisi 15. Diterjemahkan oleh A. Samik Wahab. EGC: Jakarta

Bhutta, Z. A. 2006. Clinical Review: Current Concepts in the Diagnosis and Treatment of Typhoid Fever. BMJ. 333: $78-82$

BNF. 2011. British National Formulary. BMJ Group: London

BNFC. 2011. British National Formulary for Children. BMJ Group: London

Brunton, L.L., Keith, L.P., Donald, k.B and Iain, L.O.B. 2008. Goodman \& Gillman's Manual of Pharmacology and Therapeutics. International edition. The McGraw-Hill: United State of America

Brunton, L. L., B. A. Chabner. and B. C. Knollmann. 2011. Goodman \& Gilman's - The Pharmacological Basis Of Therapeutics. Twelfth edition. McGraw-Hill Companies: China

Butler, T., C. B. Srindhar., M. K. Daga., K. Pathak., R. B. Pandit., R. Khakhria., C. N. Potkar., M. T. Zelasky., R. B. Johnson. 1999. Treatment Of Typhoid fever with azitromycin versus chloramphenicol in a randomized multicenter trial in India. Journal Of Antimicrobial Chemotherapy. 44: 243 - 250

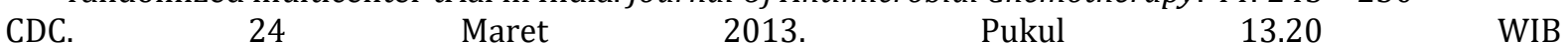
http://www.cdc.gov/nczved/divisions/dfbmd/diseases/typhoid fever/\#top 
Chowta, M. N and Chowta, M. N. 2005. Study of Clinical Profile and Antibiotic Respone in Typhoid Fever. Indian Journal of Medical Microbiology. 23(2): 125 - 127

Crump, J.A., Luby, S.P and Mintz, E.D. 2004. The Global Burner of Typhoid Fever. Bulletin of The World Health Organization. 82(5): 346 - 353

Dipiro, J.T., Barbara, G.W and Terry, L.S. 2009. Pharmacotherapy Handbook. Seventh Edition. The McGraw-Hill Companies Inc: New York

Emmeluth, D. 2004. Typhoid Fever. Infobase Publishing: New York

Frenck, R. W., Jr., Isabelle, N., Yehia, S., Samir, B. B., Youssef. F. G., John, D., Thomas, C. B., Nabil, I. G., Mosaad, M. 2000. Azithromycin versus ceftriaxone for the treatment of uncomplicated typhoid fever in children. Clinical Infectious Diseases. 31: 1134 - 11348

Gillman, A.G., Joel, G.H and Lee, E.L. 2008. Goodman \& Gilman Dasar Farmakologi Terapi. Edisi 10. Ditejemahkan oleh Amalia Hanif. EGC: Jakarta

Girgis, N. I., Sultan, Y., Hammad, O., Farid, Z. 1995. Comparison of the efficacy, safety, and cost of cefixime, ceftriaxonr, and aztreonam in the septicemia in children. Pediatr Infect Dis. 14: 603 - 605

Girgis, N.I., Thomas, B., Robbert, W.F., Yehia, S., Forrest, M.B., David, T and Rasik, K. 1999. Azithromycin Versus Ciprofloxacin For Treatment Of Uncomplicated Typhoid Fever In A Randomized Trial In Egypt That Included Patients With Multidrug Resistance. American society for microbiology. 1441-1444

Guerrant, R.L. 1990. Buku ajar Ilmu Penyakit Dalam. Edisi 2. ECG: Jakarta

Guyton, A.C., Hall, J.E. 2007. Buku Ajar Fisiologi Kedokteran. Edisi 11. Alih Bahasa : dr.Irawati. Jakarta : Penerbit Buku Kedokteran EGC

Hatta, M and Ratnawati. 2008. Enteric Fever In Endemic Areas of Indonesia : An Increasing Problem Of Resistance. J Infect Developing Countries. 2(4): 279 - 282

Islam, A., T. Butler., I. Kabir and N. H. Alam. 1993. Treatment of typhoid fever with ceftriaxone for 5 days or chloramphenicol for 14 days : a randomized clinical trial. Antimicrobial agents and chemotherapy. 37: $1572-1575$

Kadhniravan, T., Naveer, W., Arti, K., SK, Kabra, K, Renuka and Anoop, M. 2005. Clinical outcomes in typhoid fever : adverse impact of infection with nalidixic acid-resistant Salmonella typhi. BMC Infectious Diseases. 5: 37

Kalra, S.P., N. Naithani., S. R. Mehta., A. J. Swamy. 2003. Review article : Current Trends In The Management Of Typhoid Fever. MJAFI. 59(2): 130 - 135

Katzung, B. G., Susan, B. M and Anthony, J. T. 2009. Basic \& Clinical Pharmacology. Eleventh edition. International edition. McGraw-Hill: Singapore

Kaur, J. 2013. Increasing Antimicrobial Resistance and Narrowing Therapeutics in Typhoidal Salmonellae. Journal of Clinical and Diagnostic Research. 7(3): 576 - 579

Kundu, R., Nupur, G., Tapan, K. G., Vijay, N. Y., Raju, C. S., Nitin, K. S. 2006. IAP Task Force Report : Management of Enteric Fever in Children. Indian Pediatrics. 43: 884 - 887

Mengo, D.R., Sam K., Ann W., T Muigai And Gunturu N.R. 2010. Trends in Salmonella enteric serovar Typhi in Nairobi, Kenya from 2004 to 2006. J Infect Dev Ctries. 4(6): 393-396

Menkes. 2004. Standar Pelayanan Farmasi Di Rumah Sakit. Republik Indonesia : Jakarta

Menkes. 2006. Tentang Pedoman Pengendalian Demam Tifoid. No. 364/Menkes/SK/V/2006. Menteri Kesehatan. Jakarta

Menkes. 2011. Pedoman Pelayanan Kefarmasian Untuk Terapi Antibotik. Kementerian Kesehatan Republik Indonesia : Jakarta

Musnelina, L., A Fuad, A., Ascobat, G., dan Pratiwi, A. 2004. Analisis Efektivitas Biaya Pengobatan Demam Tifoid Anak Menggunakan Kloramfenikol dan Seftriakson di Rumah Sakit Fatmawati Jakarta Tahun 2001-2002. Makara. Kesehatan. 8(2): 59 - 64

Nuzirwan, A. 1995. Pola Penyakit Demam Tifoid di UPK Penyakit Dalam RSUP Dr. M. Djamil Padang (Januari-Desember 1994). Naskah lengkap simposium perkembangan terbaru terapi demam tifoid. FKUA: Padang

Ochial, R. L., Camilo, J. A., M. C. D. H., Dong, B., Sujit, K. B., Magdarina. D. A., Zulfiqar, A. B., Do, G. C., Mohammad, A., Seonghye, S., John, W., Anne, L. P., M. J. A., Jeremy. F., Remon, A. E., Tikki. P., Claidia, M. G., Lorenz. V. S., John. D. C. and The Domi Typhoid Study Group. 2008. A Study Of Thyphoid Fever In Five Asian Countries : Disease Burden And Implications For Controls. Bulletin Of World Health Organization. 86: 260 - 268

Parry, C.M., Tran T.H., Gordon D., Nicholas J W and Jeremy J.F. 2013. Review article Medical progress : Typhoid fever. The new England of medicine. 347(2): 1770 - 1782

Portnoy, D and Seah, S. 1979. Typhoid Fever : Treatment Failure And Multiple Relapses With Trimethorphim-Sulfamethoxazole And Chloramfenicol Theraphy. CMA Journal. 120: 1264-1265

Ray, K. 2002. Typhoid Fever. First Edition. The Rosen Publishing Group Inc: New York 
Riyatno, I. P dan Eman, S. 2011. Cost-Effevtiveness Analysis Pengobatan Demam Tifoid Anak Menggunakan Sefotaksim dan Kloramfenikol Di RSUD. Prof. DR. Margono Soekarjo Purmokerto. Mandala of Health. $5(2):$

Smith, M. D., Duong, N. M., Hoa, N. T., Wain, J., Ha, H. D., Diep, T. S., Day, N. P., Hien, T. T., White, N. J. 1994. Comperison of Ofloxacin and Ceftriaxone for Short-course Treatment of Enteric Fever. Antimicrobial Agents and Chemotherapy. 38: 1716 - 1720

Sudoyo, A.W., Bambang, S., Idrus, A., Marcellus, S.K dan Siti, S. 2007. Buku Ajar Ilmu Penyakit Dalam. Jilid III. Edisi IV. Pusat Penerbitan Departemen Ilmu Penyakit Dalam Fakultas Universitas Indonesia: Jakarta Pusat

Suharyo, H. 1997. Prevention and Control of Typhoid Fever : Proceedings of the Third Asia-Pacific Symposium on Typhoid Fever and Other Salmonellosis. Medical Journal of Indonesia. 8(1): 117 - 123

Sweetman, S. C. 2009. Martindale : The Complete Drug Reference. Thirty sixth edition. Pharmaceutical press : China

Thapa, R., Nalin, B., Jhapindra, P., Bishnu, H. S., Buddha, B. 2010. Another Typhoid Patient From Japan. Journal Of Travel Medicine. 17(3). 199 - 200

Timmreck, T. C. 2004. Epidemiologi : Suatu Pengantar. Edisi 2. Diterjemahkan oleh Munaya Fauziah. EGC : Jakarta

Virella, G. 2001. Medical Immunology : Revised and Expandel. Fifth edition. Marcel Dekker : New York Walker. 2004. Pediatric Gastrointestinal Disease, Volume One, Fourth Edition, BC Decker Inc: United State WHO. 2003. The Department of Vaccines and biological 